KRZYSZTOF GoźDŹ-RosZKowsKI

\title{
O obowiqzku rozdawania skonfiskowanych dóbr ziemskich w ustawodawstwie polskim XVII-XVIII wieku
}

\author{
Vermerke über Vergabepflicht der beschlagnahmten Bodengüter \\ in der polnischen Gesetzgebung im 17. und 18. Jahrhundert
}

1. Uwagi wstępne. 2. Obowiązywanie normy ogólnej z 1576 r. i szczegółowe postanowienia późniejszych ustaw. 3. Wyjątki od zasady rozdawania dóbr. 4. Podział dóbr na dwie części i jego konsekwencje. 5. Uwagi końcowe.

1. Vorbemerkungen. 2. Gültigkeit der allgemeinen Norm vom 1576 und genaue Beschlüsse der späteren Gesetze. 3. Ausnahmen von der Regel über Vergabe der Güter. 4. Einteilung der Güter in 2 Teilen und ihre Konsequenzen. 5. Schlussbemerkungen.

1. Król w Rzeczypospolitej byl - jak wiadomo - zobowiązany do rozdawania dóbr ziemskich ulegających karze konfiskaty. Obowiązek ten, ukształtowany zwyczajowo $w$ odniesieniu do dóbr podlegających przepadkowi za niektóre rodzaje przestępstw, sformułowała jako ogólną regułę przyjęta na sejmie egzekucyjnym z lat $1562 / 63$ ustawa $O$ karaniu wystepnych. Rozdawnictwu podlegała bowiem odtąd każda taka majętność - niezależnie od rodzaju przestępstwa, które powodowało jej konfiskatę. $\mathrm{Na}$ podkreślenie zasługuje fakt, iż obowiązek rozdawania zostal w $1576 \mathrm{r}$. rozszerzony przez konstytucje $O$ dobrach iuris caduci $i$ wakancjach na wszelkie dobra przychodzące do dyspozycji panującego, a nie stanowiące królewszczyzn ${ }^{1}$.

Chociaż w dziejach królewskiej gratiae distributivae wspomniana ustawa wyznaczała istotny moment, to jednak kwestia przeznaczenia majętności na podstawie różnych tytułów przypadających skarbowi, zwłaszcza $\mathrm{z}$ powodu konfiskaty, pozostawała nadal w sferze zainteresowania ustawodawstwa.

${ }^{1} \mathrm{~K}$. G oźdz-R os zk ow ski, Obowiqzek rozdawania dóbr skonfiskowanych w ustawodawstwie polskim XVI stulecia, Zesz. Nauk. UŁ 1971, S. I, z. 83, s. 15-36. Szerzej t e nż e, Rozdawnictwo skonfiskowanych dobr ziemskich $w$ prawie polskim $X V-X V I$ wieku, Studia nad Historią Państwa i Prawa [Wrocław-Warszawa-Kraków-Gdańsk] 1974, S. II, t. XIV, s. 18-34. 
Powracają do niej konstytucje sejmowe aż do schyłku istnienia dawnej Rzeczypospolitej.

Poczynione niżej spostrzeżenia dotyczą samego tylko istnienia po $1576 \mathrm{r}$. obowiązku nadawania majątków ulegających konfiskacie, bez wchodzenia w szereg kwestii szczególowych, jakie nasuwają ustawy wydane w rozpatrywanym okresie.

2.1. W dwanaście lat po uchwaleniu konstytucji $O$ dobrach iuris caduci $i$ wakancjach sejm potwierdzil jej moc obowiązującą w ustawie $O$ kadukach: Konstytucya Koronacyi Krola Stefana Przodka naszego slawney pamieci o rozdawaniu dóbr jure caduco, inscripto, donato seu alio quocunque modo et ratione ad fiscum nostrum Regium juste et legitime przypadlych y ktore przypadać będa uczynionq $w$ mocy zachowuiemy z tq deklaracyq... ${ }^{2}$

Ustawodawca określil następnie, kiedy dobra szlacheckie stanowią spadek bezdziedziczny (kaduk) i wobec tego podlegają obowiązkowemu rozdawnictwu ze strony króla, formułując znane postanowienie o prawie krewnych do dziedziczenia - aż do ósmego stopnia w linii bocznej ${ }^{3}$. Unormował też niektóre kwestie dotyczące kaduków w miastach królewskich, a także w miastach i wsiach prywatnych. Zwracają uwagę przepisy wymierzone przeciwko tym, którzy by wyjednali u króla nadanie na dobra nie stanowiące $\mathrm{w}$ istocie kaduka.

Wskazane postanowienia miały zabezpieczyć szlacheckich posesjonatów przed negatywnymi skutkami wykonywania przez króla óbowiązku rozdawnictwa. Ustawodawca wyraźnie bowiem uzupełnia istniejący od $1576 \mathrm{r}$. obowiązek dystrybucji owymi postanowieniami po to, aby kto nomine caduci nie byl $w$ dobrach swoich uszkodzon albo uciśnion ${ }^{4}$. Być może kilkunastoletni okres obowiązywania ustawy z 1576 r. ujawnił owe skutki na tyle mocno, iż okazało się koniecznym jej uzupełnienie. W takim razie jednak obowiązek rozdawania - przynajmniej w odniesieniu do dóbr stanowiących spadek bezdziedziczny - musiał być przez króla wykonywany. W jakim wszakże stopniu konstytucja z 1576 r. była realizowana w praktyce, to jest kwestia dla osobnych badań. Wydaje się jednak, iż potwierdzenie mocy obowiązującej tej ustawy w $1588 \mathrm{r}$. nie daje podstaw, aby przypuszczać, iż poszla w zapomnienie.

Odmienną refleksję nasuwa konstytucja z 1607 r.: W rozdawaniu kaduków tak, iako iest konstytucya o tym uczyniona zachować sie mamy. Znajdujemy

\footnotetext{
${ }^{2}$ VL 2, f. 1209 , nr 8 (1588 r.).

${ }^{3}$ P. D ąbk owski, Prawo prywatne polskie, t. 2, Lwów 1911, s. 15.

${ }^{4}$ Zob. wyżej przyp. 2. Podobnie S. P ła z a zauważa ochronny charakter normy rozszerzającej prawa do spadku na krewnych bocznych, t e n że, Historia prawa w Polsce na tle porównawczym, cz. I: X-XVIII w., Kraków 1997, s. 299.

s VL 2, f. 1606-1607, nr 23: „O kadukach”.
} 
w cytowanym tekście kolejne stwierdzenie mocy obowiązującej ustawy z 1576 r., której król, gdy szło o spadki bezdziedziczne, widocznie mało przestrzegal. Toteż sejm z $1607 \mathrm{r}$. zobowiązal monarchę do wykonywania sformułowanego tam obowiązku ich rozdawania.

Również konstytucja z 1631 r., ustanawiając zasadę, iż dobra ziemskie może nabywać jedynie szlachta, potwierdzała ustawę z 1576 r.: ...zostawuiqc sobie wcale prawo nasze de jure caduco, inscripto, donato; tak iednak, że te dobra Nam tali modo przypadle, wedlug tychże praw indigenis nobilibus utriusque gentis rozdawać będziemy ${ }^{6}$. W tym jednak wypadku można odnieść wrażenie, iż postanowienie ustawy wiązało się nie tyle $z$ lekceważeniem przez króla obowiązku rozdawnictwa, co bardziej z wykonywaniem go w sposób sprzeczny z normą z $1576 \mathrm{r}$, nakazującą monarsze dawać przypadające mu majętności szlachcie, a do tego bene meritis. Ustanawiając wylączność szlachty na posiadanie dóbr ziemskich, należało zamknąć plebejom dostęp do nich również poprzez królewskie rozdawnictwo.

2.2. Oprócz postanowień wskazujących na obowiązywanie w ustawodawstwie również i po $1576 \mathrm{r}$. obowiązku rozdawania wszelkich nieruchomości ziemskich stanowiących nowy nabytek skarbu, a więc i dóbr skonfiskowanych, pojawiają się także konstytucje zawierające normy dotyczące wyłącznie dystrybucji tych ostatnich.

Ustawa z 1607 r. nakazywała rozdać dobra osób, które podczas wojny z Karolem Sudermańskim uzyskały podstępnie u króla nadania na majętności znajdujące się w Inflantach ${ }^{7}$. Król mial też nadawać dobra szafarzy, poborców i arendarzy ,wszelakich podatków”, o ile nie oddadzą zgromadzonych pieniędzy w wyznaczonym przez sejm terminie ${ }^{8}$. Także dobra tych, którzy otrzymali indygenat wbrew postanowieniom ustawy z $1607 \mathrm{r}$. , i majętności osób czyniących zaciągi wojskowe bez zgody sejmu, a jedynie na podstawie przypowiednich listów z pieczęcia albo sygnetem pokojowym królewskim $^{10}$ oraz dopuszczających się określonych ustawami przestępstw wojskowych ${ }^{11}$, również dobra sprawców różnych przestępstw nie korzystających $\mathrm{z}$ amnestii przewidzianej $\mathrm{w}$ ustawie $\mathrm{z} 1624 \mathrm{r}^{12}$

Pojawianie się szczegółowych postanowień, mimo obowiązywania ogólnej zasady rozdawania wszelkich nowych nabytków skarbu, pozwala przypuszczać,

"VL 3, f. 666, nr 4: „O dobrach ziemskich dziedzicznych".

'VL 2, f. 1613: „Ordynacya Ziemie Inflantckiey”.

"VL 3, f. 243: „Naznaczenie zapłaty żotnierzom” art. 6. (1613 r.). Zob. też VL 4, f. 70: „Zaplata woysku ukrainnemu” (1643 r.)

${ }^{9} \mathrm{VL} 4, \mathrm{f} .11$, $\mathrm{nr} 11$ : „O indygenatach y nobilitacyach".

${ }^{10} \mathrm{VL} 4$, f. 84: "O zaciągu nowego woyska..." (1646 r.).

$"$ VL 4, f. 447: „Zatrzymanie woyska w służbie Rzepltey” (1654 r.), ibidem, f. 490: „O swowolnych wolontaryuszach..." (1655 r.); VL 5, f. 362: „O swawolnych za granica zaciągach osób Koronnych y Wielkiego X. Litew." (1676 r.).

12 VL 3, f. 464: „Postanowienie na domową obronę względem swywolnikow”. 
że praktyka - w wypadku dóbr skonfiskowanych - od niej odbiegała ${ }^{13}$. Pretekst ku temu - co paradoksalne - dawałaby królowi formułująca wspomnianą zasadę konstytucja z 1576 r., która nie wymieniała wyraźnie majętności pochodzących $\mathrm{z}$ konfiskaty ${ }^{14}$.

3. Trzeba wspomnieć też, że pojawiały się ustawy, które odstępując od zasady wyrażonej w konstytucji z 1576 r., odmiennie normowały przeznaczenie dóbr skonfiskowanych.

Sejm 1676 r. uchwalając pospolite ruszenie, postanowit: Absentes $w$ generalnym obozie osadzeni bydź powinni y dobra ich in communem fiscum na zaplate woysku obrocone beda ${ }^{15}$. Natomiast ustawa z $1601 \mathrm{r}$. przeznaczała całość majętności osoby fałszywie świadczącej w procesie o naganę szlachectwa temu, kto pozwie fałszywego świadka przed sąd ${ }^{16}$. Nadanie królewskie do osiągnięcia takich dóbr nie bylo potrzebne. Legitymacja procesowa powoda wynikała bowiem z ustawy ${ }^{17}$.

Postanowienia wyłączające dystrybucję, a więc bardziej korzystne dla skarbu, pojawiały się również pod koniec XVIII stulecia. Na przytoczenie zasługuje przepis konstytucji z $1789 \mathrm{r}$., wymierzony przeciwko posesorom dóbr udaremniającym ściągnięcie podatku zwanego ofiarą dziesiątego grosza: ...takowy iako nieprzyiaciel oyczyzny, prawu nieposiuszny, wlasność w oyczyźnie utraci a maiqtek iego plus offerenti, na wieczny czynsz [...] przedany na użytek skarbu zostanie... ${ }^{18}$ Tendencje do ograniczenia rozdawnictwa wydaja się zrozumiale w czasach Sejmu Czteroletniego, kiedy to $\mathrm{z}$ wielkim wysiłkiem szukano źródeł powiększenia zasobów skarbu, który mial sprostać potrzebom wojskowym państwa zagrożonego w swym bycie politycznym.

${ }^{13}$ Konstytucja z 1646 r. upoważniała nawet posłów do upominania się u króla podczas sejmu, aby rozdał dobra ulegające konfiskacie za określone w niej przestępstwo, VL 4, f. 84-85: "O zaciągu nowego woyska...".

${ }^{14} \mathrm{~K}$. Goźdź-R os zk owski, Obowiqzek rozdawania..., s. 26.

${ }^{15}$ VL 5, f. 339: „Pospolite ruszenie”. Wśród uchwał sejmu z 1674 r. znajdujemy następujące postanowienie: $A$ skarb dobra retentorów [15 podymnych, uchwalonych na opłacenie wojska - uzup. K.G.R.] contravenientium na kommissyi osqdzonych przez dworzanina przy Poborcach konfiszkować y one $w$ zaslugach za dekretami kommissyi Deputatom od choragwi naznaczonym podawać ma (ibidem, f. 230). Prawdopodobnie przewidywało ono nie tyle konfiskatę, co sekwestr dóbr należących do retentorów, z których wojsko miało samo wyegzekwować należny sobie żołd.

16 VL 2, f. 1503: „O nowey szlachcie"; A. Z. He1cel, Dawne prawo prywatne polskie, Kraków 1874, s. 75.

${ }^{17}$ A. Z. Helcel słusznie widział w powodzie delatora. Tenże, Dawne prawo..., s. 75 . Co do delatora zob. dalej pkt 4.4 .

${ }^{18}$ Sposób wynalezienia ofiary $z$ dóbr ziemskich i duchownych $w$ Koronie i w Wiekim Xsięstwie Lit., VL 9, s. 94, art. 12. 
Brak rozdawnictwa nie zawsze jednak oznaczał w tym czasie przyjęcie przez ustawodawcę rozwiązania korzystnego pod względem fiskalnym. Ustawa z 1791 r. stanowiła bowiem, że dobra ukaranych konfiskatą tych uczestników buntu, których uznano za mniej winnych, oraz pomocników w przestępstwie miały w takowym przypadku [...] spadać na prawych sukcessorów ${ }^{19}$. Inne postanowienie $\mathrm{z}$ tego samego roku przewidywało dla osób skazanych za branie od potencyi zagranicznych pieniędzy, oprócz kary śmierci, utratę jednej ósmej majątku, która przypadała, $\mathrm{z}$ pominięciem nadania, delatorowi ${ }^{20}$.

4.1. $Z$ podziałem na dwie części dóbr ulegających konfiskacie spotykamy się już w konstytucji z 1567 r., skierowanej przeciw tym, którzy wbrew postanowieniom wcześniejszych statutów, ze szkodą dla skarbu używali „zamorskiej soli”: ...tedy takowy ma bydź karan confiscatione bonorum, polowica Nam, a druga czwartej części na slużebne Rzeczypospolitey... ${ }^{21}$

W 1574 r. skonfederowana szlachta województwa krakowskiego postanowila za absencje na okazowaniu karę konfiskaty, ktorej peny potowica ad fiscum a polowica delatorowi być $m a^{22}$. Taki sam podział $\mathrm{w}$ odniesieniu do dóbr ziemskich trzymanych wbrew prawu przez plebejów przewidywała instrukcja z 1584 r., dana posłom przez sejmik województwa krakowskiego w Proszowicach $^{23}$.

Żądanie szlachty małopolskiej, by delator partycypował w połowie dóbr ulegających konfiskacie, zostało wkrótce zaspokojone, ale w odniesieniu do majątku osób uzurpujących sobie szlachectwo. Konstytucja z 1589 r. stanowiła bowiem, aby ten, komu dowiodą to przestępstwo, dobra swoie tracil polowice do quarty, a polowice do delatora... ${ }^{24}$

Późniejsze ustawodawstwo dzieliło majętności podlegające przepadkowi na dwie polowy: pomiędzy skarb królewski i delatora. Należy tu wymienić konstytucje z 1601 i $1609 \mathrm{r}^{25}$ zakazujące cudzoziemcom nabywać dobra ziemskie ${ }^{26}$, konstytucję z 1611 r., która stanowiła za fałszowanie monety

19 "Sądy seymowe", VL 9, s. 244-245, art. VIII.

20 „Deklaracya”, VL 9, s. 203.

${ }^{21}$ VL 2, f. 726: "O soli".

${ }^{22}$ Akta sejmikowe województwa krakowskiego, t. 1, 1572-1620, wyd. S. Kutrzeba, Kraków 1932 , s. $41-42$.

${ }^{23}$ Ibidem, s. 104.

${ }^{24}$ VL 2, f. 1272: „O szlachectwie”. A. Z. Helcel, Dawne prawo.., s. 75; J. M a k a rewicz, Polskie prawo karne, część ogólna, Lwów-Warszawa 1919, s. 274; J. S. M a t u s ze wsk i, Nagana szlachectwa w Polsce $w$ XV i XVI wieku, Zesz. Nauk. UL 1971, S. I, z. 77, s. 139.

${ }^{25}$ VL 2, f. 1510: „Cudzoziemcy dobr ziemskich kupować nie maiq̨", ibidem, f. 1676: „De plebeijs...”.

${ }^{26}$ P. S k warczyń sk i zauważył, iż wcześniejsza od nich konstytucja, z 1589 r., przyznawała takie dobra w całości skarbowi koronnemu. T e nże, Stanowisko cudzoziemców w dawnem prawie polskiem koronnem, Pamiętnik Historyczno-Prawny [red. P. Dąbkowski, Lwów] 1931, t. XI, z. 1, s. 17. 
karę infamii oraz konfiskaty dóbr ${ }^{27}$, ustawę z $1662 \mathrm{r}$. - rozciągającą rygory konstytucji 1658 r. na żony arian i ich służebnice, pozostające przy wyznaniu ariańskim $^{28}$, konstytucję z 1726 r. - reasumującą wcześniejsze ustawy amortyzacyjne ${ }^{29}$, a także ustawę z 1764 r. zabraniającą neofitom posiadać dobra ziemskie ${ }^{30}$.

Warto na koniec wspomnieć, iż ostatni sejm Rzeczypospolitej, stanowiąc kare konfiskaty na zamieszkujących w Polsce Francuzów oskarżonych o związki z rewolucyjnym reżimem swej ojczyzny, przeznaczył trzy czwarte ich majątku na profit szpitalów, a tylko jedną czwartą delatorowi ${ }^{31}$.

4.2. Ustawy z lat 1567 i 1589 , przeznaczające połowę dóbr ulegających konfiskacie na rzecz kwarty, powodowały co do tej części zmianę ich przeznaczenia. Wspomniana połowa miała bowiem powiększać pulę królewszczyzn. W dysponowaniu nimi monarcha zostal - jak wiadomo - przez sejmy egzekucyjne mocno ograniczony. Nie mogły być przedmiotem darowizny $^{32}$. Korzystne dla skarbu postanowienia ustaw z 1567 i 1589 r. mialy jednak charakter wyjątkowy. Późniejsze ustawodawstwo nie powróciło już do koncepcji obracania części skonfiskowanych dóbr na rzecz kwarty.

4.3. Wprawdzie połowa konfiskowanych majętności - jak zauważyliśmy - przypadała fisco Regio ${ }^{33}$, to jednak król nie mial prawa takich nabytków zatrzymywać, lecz na zasadzie ustaw z lat 1562/63 i 1576 powinien był je dać szlachcie. Wyraźnie o nadaniu mówila konstytucja z 1726 r.: ...y wszelkie takowe dobra [...] confiscationi subjacere maiq, ktorych polowica delatori, a druga polowa ad distributivam justitiam nostram, jure caduco, personae nobili conferendo należé $\mathrm{ma}^{34}$.

4.4. Od dawna $w$ praktyce król wykonując obowiązek rozdawnictwa, przyznawał dobra głównie tym spośród szlachty, którzy donieśli o przestępstwie $^{35}$. Akt nadania dawal delatorowi legitymację niezbędną do wszczęcia

27 VL 3, f. 12: „O mynnicy fałszywey”.

${ }^{28}$ VL 5, f. 830: "O Aryanach".

${ }^{29}$ VL 6, f. 488: "Warunek de non alienandis bonis od Stanu rycerskiego y mieyskiego do duchowieństwa". J. M a zurkiewicz, Ustawy amortyzacyjne $w$ dawnej Polsce, Pamiętnik Historyczno-Prawny [Lwów] 1933, t. 12, z. 2, s. 42; J. R a f a c z, Dawne prawo sqdowe polskie $w$ zarysie, Warszawa 1936, s. 207

${ }^{30}$ VL 7, f. 74: „Neofici”.

${ }^{31}$ „Zalecenie władzom krajowym względem Francuzów” (1793 r.), VL 10, s. 86.

${ }^{32}$ Statut Aleksandrow o dobrach stolice naszey Królewskiey deklaruiqc zwalamy, aby dziedzictwa ani lenna wieczne nie byly nigdy dawane, VL 2, f. 681: „Statut Aleksandrow” (1565 r.).

${ }^{33}$ Tak ustawa 1609 r., VL 2, f. 1676 . i ustawa z 1601: polowica fisco nostro Regio, ibidem, f. 1510. Inne krótko, jak na przykład medietas fisco [...] cedere ma, VL 4, f. 830.

${ }^{34}$ VL 6, f. 488: „Warunek de non alienandis bonis od Stanu rycerskiego y mieyskiego do duchowieństwa". Obowiązek króla rozdawania połowy dóbr ulegających konfiskacie zauważył J. R a facz, Dawne prawo..., s. 207, a także J. M a z u rki ew icz, Ustawy amortyzacyjne..., s. 42.

${ }^{35} \mathrm{~K}$. Goźdź-R oszk owski, Rozdawnictwo..., s. 57-60 oraz ibidem, s. 63-65. 
procesu windykacyjnego przeciwko osobie, której majętność uległa dystrybucjii ${ }^{36}$. Można jednak wnosić, że konstytucje dając delatorowi część skonfiskowanego majątku, stawiały go w innej pozycji niż ta, jaką zajmował zwykły denuncjant.

Przyjrzyjmy się bliżej ustawom z lat 1601 i 1609 . Pierwsza - jak wiemy - zakazala cudzoziemcom kupować dobra ziemskie ...pod utraceniem teyże kupioney maiętności, ktorej polowica fisco nostro Regio, a druga delatori cedet $^{37}$. Druga, skoro najwidoczniej dotychczasowe postanowienia nie odnosily skutku, obostrzyła sankcję i co ważne - sprecyzowała sposób ścigania: ...aby, inhaerendo prioribus constitutionibus, na Trybunale od kogożkolwiek pozwani [...] a slusznemi dowody convicti, maiętności swych fisco Regio polowice, delatori jure victori przepadali $y$ na siedzenie $w$ wieży skazani byli... ${ }^{38}$

Jak widać, legitymację procesową miał każdy szlachcic, który wiedział, iż cudzoziemiec wbrew zakazom posiada dobra ziemskie, a nie tylko posiadający królewski akt nadania. W razie dowiedzenia winy, sąd mial orzec przepadek owych dóbr $w$ polowie na rzecz powoda-delatora, a w polowie - na rzecz króla, a nadto karę wieży.

Rozpatrywane postanowienia ukazują korzystną sytuację prawną delatora. Służyło mu bowiem prawo do skonfiskowanego majątku samoistne, płynące wprost $\mathrm{z}$ ustawy, a stąd i legitymacja procesowa do jego windykacji. Wobec czego, królewski akt nadania nie byl delatorowi potrzebny do wytoczenia o nie procesu. Zarysowana tu pozycja delatora nie ograniczała się zapewne do wypadków dzierżenia wbrew zakazom dóbr przez cudzoziemców ${ }^{39}$.

Wynika ona również z rozpatrywanej wcześniej ustawy z 1601 r. O nowej szlachcie $^{40}$. W nauce uważa się, że delator był samodzielnym oskarżycielem przy przestępstwach prywatnych, a przy publicznych występował obok instygatora ${ }^{41}$. Można przeto $\mathrm{w}$ postanowieniach ustaw przyznających mu część (rzadko całość) ulegających konfiskacie majętności dopatrywać się ograniczenia rozdawnictwa monarszego ${ }^{42}$.

\footnotetext{
${ }^{36}$ Ibidem, s. 45-47.

${ }^{37}$ VL 2, f. 1510: "Cudzoziemcy dobr ziemskich kupować nie maią".

${ }^{38}$ VL 2, f. 1676: „De plebeijs...".

${ }^{39}$ Prawo do połowy dóbr służyło ex lege delatorowi - zdaniem J. M a zurki ewicza - na podstawie ustawy z $1726 \mathrm{r}$. Tenże, Ustawy amortyzacyjne..., s. 42. J. M ak a rewicz uważał, iż delator, któremu konstytucja z 1589 r. przyznawała połowę dóbr osoby udającej szlachcica, nie był denuncjantem, lecz samoistnym oskarżycielem, którego prawo zachęca do wniesienia skargi premią. T enże, Polskie prawo..., s. 274, a także s. 67.

${ }^{40}$ Zob. wyżej pkt 3.

${ }^{41}$ J. M a ka rewicz, Polskie prawo..., s. 62, 63, 65, 66; S. Plaz a, Historia prawa..., s. 481.

42 Jednakże praktyka bywała różna, jak wynika z przykładów podanych przez W. Lozińskiego, dotyczących dóbr ulegających konfiskacie $z$ powodu uzurpowania sobie szlachectwa przez ich właścicieli. Bywało, iż delator występował do sądu $z$ żądaniem dóbr na rzecz swoja i skarbu, ale także zdarzało się, iż uzyskiwał na całość dóbr przywilej nađawczy z kancelarii
} 
5. Rozdawanie dóbr ulegających karze konfiskaty pozostało w ustawodawstwie również i po 1576 r. obowiązkiem monarchy. W badanym okresie obowiązek ten zmienił swój charakter wobec pojawienia się postanowień wyłączających dobra skonfiskowane w calości spod dystrybucji królewskiej. Charakterystycznym staje się też przeznaczanie do dyspozycji króla tylko połowy ulegającej przepadkowi majętności, gdy tymczasem przeznaczenie drugiej było odmienne. Jeśli miała ona powiększyć dochody skarbu kwarcianego, stając się w konsekwencji królewszczyzną, to darowizna owej części okazywała się niedopuszczalna. Zazwyczaj jednak konstytucje sejmowe przeznaczały połowę dóbr delatorowi. Wówczas nadanie królewskie stawało się zbędne, ponieważ sama ustawa dawała mu legitymację do wystąpienia na drogę sądową.

Obserwujemy zatem w ustawodawstwie znamienną tendencję: przy zagwarantowaniu prawa szlachty do przejmowania skonfiskowanych majętności, równocześnie stałemu ograniczaniu ulega władza monarsza - królewska gratia distributiva.

królewskiej. Te nże, Prawem $i$ lewem. Obyczaje na Czerwonej Rusi w pierwszej polowie XVII w., t. 1, Kraków 1960, s. 271-274. Warto też zacytować interesującą uwage Lozińskiego: nie spotkaliśmy sie $z$ wypadkiem, aby udowodniona uzurpacja szlachectwa sprowadzila za sobq rzeczywiście konfiskate dóbr i podzial ich między skarb królewski a delatora. Nawet ostateczny wyrok trybunalu, przysqdzajqcy ten podzial, jeszcze nie rozstrzygal sprawy, ibidem, s. 274. 